\title{
Possible role of complement factors and their inhibitors in the myocardial infarction: an immunohistochemical study
}

\author{
TOMASZ ILCZUK, ALEKSANDER WASIUTYNSKI, EWA WILCZEK, BARBARA GORNICKA
}

Department of Pathology, Medical University of Warsaw, Warsaw, Poland

\begin{abstract}
Ongoing development of our civilization is accompanied by a marked increase of incidence of cardiovascular diseases and cardiovascular mortality. Ischemic heart disease with its extreme form - myocardial infarction - is one of the main problems of modern medicine. Despite much research devoted to this disease entity, its pathomechanism remains incompletely understood. Basing on research reports, more and more emphasis is put on immune reactions in the myocardium. Available literature lacks detailed studies examining the role of complement system and its inhibitors in the development and pathogenesis of myocardial infarction. Cells of ischemic myocardium were proven to become foreign antigens for the immune system of the patient's body. This results in complement activation of formation of so called membrane attacking complex that injures myocardial cells. By binding to its surface, it extends the myocardial destruction caused by the infarction itself.

Results of immunochemistry studies presented in this paper have demonstrated the existence colocalization of complement components (C4d,C9) and membrane inhibitors (CD55, CD59) as well as soluble inhibitors (factor $H$ ) of the complement in the examined muscle tissue that underwent ischemic necrosis. Positive immunohistochemical reaction was found in the myocardial cells, intercellular matrix and blood vessels.
\end{abstract}

Key words: complement system, complement inhibitors, myocardial infarction.

(Centr Eur J Immunol 2014; 39 (2): 253-259)

\section{Introduction}

Ischemic heart disease with its extreme form - myocardial infarction - is one of the main problems of modern medicine. Apart from the increased number of premature deaths, it carries serious psychosocial and economic consequences, i.e. marked loss of productivity, worsening quality of life and increasing costs of treatment of this vast group of patients [1]. There are many potential reasons that could lead to the exacerbation of ischemic heart disease and resulting myocardial infarction. Existence of multiple risk factors and their heterogeneous strength hamper attempts of their classification. One of the simplest and oldest classification identifies two groups: modifiable and nonmodifiable factors. The first group includes e.g. cigarette smoking, improper diet, low physical activity, dyslipidemia, including increased LDL cholesterol concentration and reduced HDL cholesterol concentration as well as presence of certain diseases, e.g. hypertension, hyperglycemia/diabetes mellitus, obesity, presence of vascular disease caused by atherosclerosis. Nonmodifiable factors include age (men $>45$ years, women $>55$ years), male gender, family history of premature cardiovascular disease caused by atherosclerosis (men $<55$ years, women $<65$ years) as well as genetic predisposition [2,3]. Despite widely available information and numerous research reports, many aspects of these disorders remain unclear. At the current state of development of biomedical sciences it is believed that dynamics of development of cardiovascular diseases are modulated by many immunological, biochemical and biophysical factors of genetic and environmental nature [4].

To understand the issues raised in this paper, we must start by defining components of the examined structure and processes on its surface, since it will allow us to move swiftly through the presented topic.

Myocardial infarction is a clinical diagnosis based on clinical events in combination with laboratory tests. When these criteria are met, diagnosis of myocardial infarction is established. Myocardial infarction was differently diagnosed by physicians and scientists in routine clinical practice and in research studies, which was the cause of confusion. To resolve these problems, the European Society of Cardiology, American College of Cardiology, American

Correspondence: Tomasz Ilczuk, Department of Pathology, Medical University of Warsaw, Chalubinskiego 5, 02-004 Warsaw, Poland, tel. 0791584 498, fax +48 2262998 92, e-mail: tomasz.ilczuk@wum.edu.pl 
Heart Association and World Health Federation in 2000 agreed and published a report that included an international and commonly accepted definition of myocardial infarction. Progress of research and numerous reports provided new data directly related to certain aspects of this definition. Therefore, an international expert group was founded and in 2007 it published a new definition of myocardial infarction. This definition is still valid [5-8].

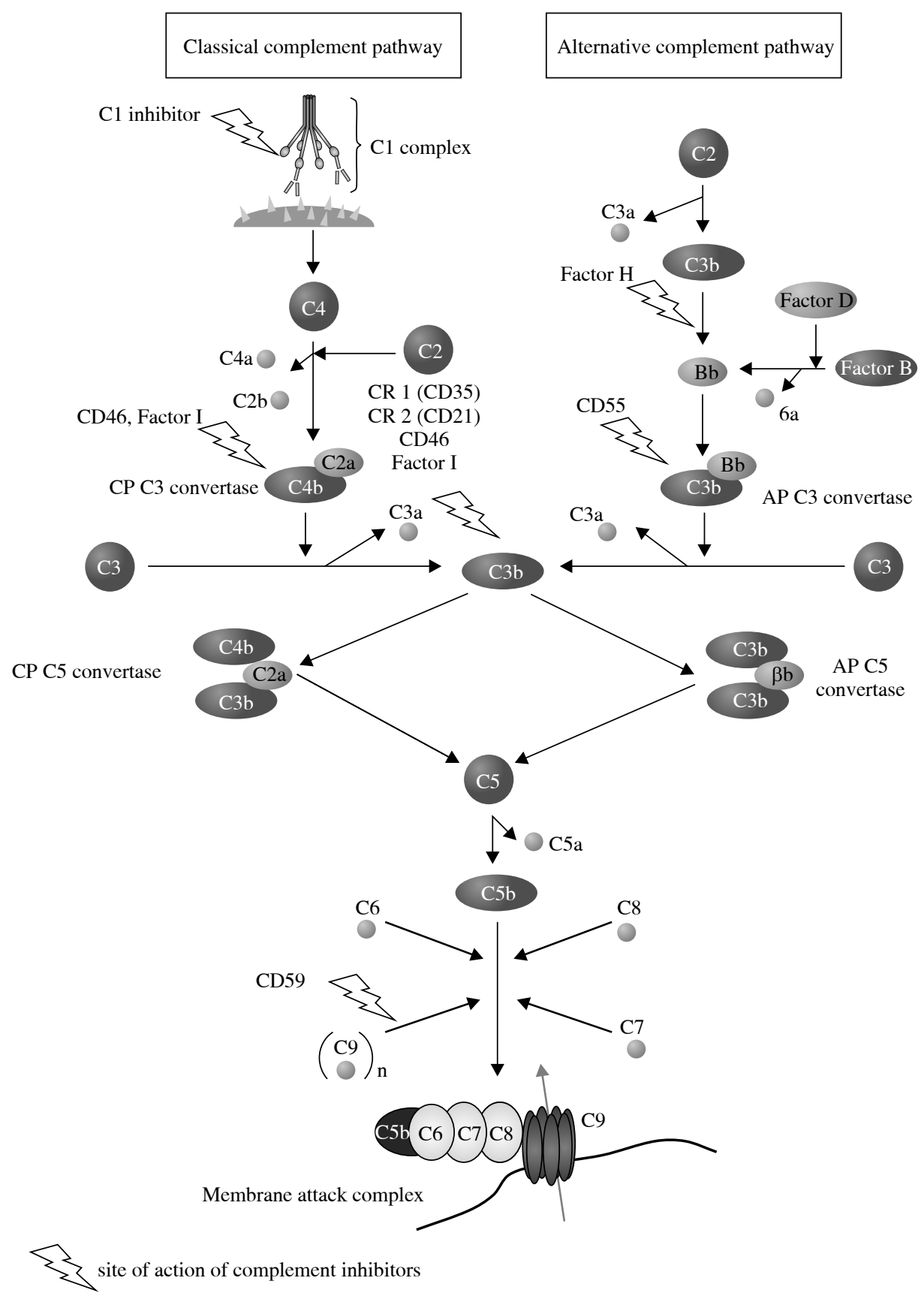

The complement system is a set of approximately 40 proteins that are present in the plasma and other body fluids along with their functionally related numerous receptors and regulatory proteins. The complement fulfills an important role in congenital, humoral mechanisms of unspecific immune response [9]. Complement activation (Fig. 1) involves a cascade of enzymatic and nonenzymatic reactions. The process of complement activation results in 
formation of two important enzymes: C3 and C5 convertase that strongly potentiate its effects. However, irrespective of the method of its activation, final stages of all these reactions are identical and involve formation of a membrane attacking complex (MAC) that is composed of C5b, C6, C7, C8 and polymeric C9 [10, 11]. The complement system requires regulation, which is supported by examples of pathologies caused by its excessive activation. For this purpose, there is a system of proteins in the plasma and on the surface of cellular membranes that regulate (control) activity of the complement. These factors have inactivating effects and result in shortening of already short half-life of convertase $\mathrm{C} 3$ and $\mathrm{C} 5$. Factor $\mathrm{H}$ is one of plasma regulatory factors; it binds $\mathrm{C} 3 \mathrm{~b}$ and facilitates factor I in inhibiting convertase $\mathrm{C} 3$. Factors that are present on cells are responsible for scavenging complement include: membrane cofactor protein $(\mathrm{CD} 46)$ - binding $\mathrm{C} 3 \mathrm{~b}$ and $\mathrm{C} 4 \mathrm{~b}$, present on essentially all nuclear cells of the body; decay-accelerating factor (CD55) - dramatically shortens half-life of convertases; homologous restriction factors (CD59) - bind C8 and C9, inhibiting formation of MAC $[9,12,13]$.

The aim of this study was to evaluate involvement of congenital, humoral mechanisms of unspecific immune response in myocardial infarction. The analysis included components C4d, C9 and membrane inhibitors CD55, CD59, and serum inhibitor, factor $\mathrm{H}$, of the complement system.

\section{Material and methods}

Tissue specimens used in the study were fixed in $4 \%$ formalin solution and embedded in paraffin according to the routine procedure. Paraffin blocks were taken from the archives of the Chair and Department of Pathology, Medical University of Warsaw. The complement proteins and inhibitors were studied in tissue specimens from 5 subjects who underwent autopsy (done within 2 days of their death).
The paraffin sections were routinely stained with hematoxylin and eosin and with immunohistochemical tracers. The following antibodies were used to detect the complement components and their inhibitors in the tested tissue material: - Mouse Anti Human CD55 (AbD Serotec, UK);

- Mouse Anti Human CD59 (AbD Serotec, UK);

- Anitbody to Human Factor H (Quidel, USA);

- Anti Human C4d Antibody (Oxford Biosystems, UK);

- Human Complement Component C9 (Novocastra, UK).

The immunohistochemical reaction was conducted in the following manner: routinely deparaffinized sections were treated with $3 \%$ hydrogen peroxide to block an endogenous peroxidase and with 5\% normal donkey serum (NDS) (Jackson Immunoresearch, USA), and subsequently solutions of primary antibodies were added. Then the reaction was incubated in a humid chamber overnight at $+4 \mathrm{C}$. A peroxidase-conjugated set of secondary antibodies ImmPress Reagent Kit Anti-Mouse Ig (Vector Laboratories, USA) was used to detect primary antibodies, while anti-goat peroxidase conjugated antibodies were used to detect goat antibodies. 3-3' diaminobenzidine (Dako, Denmark) was used as a chromogen. Subsequently hematoxylin-stained sections were dehydrated and closed as preparations. Results of the reaction were analyzed using Nikon Eclipse 80i (Nikon, Japan).

\section{Results}

To evaluate the structure of the examined muscle tissue, routine hematoxylin and eosin staining was performed. The staining demonstrated necrosis at different stages of development. Coagulation necrosis and necrotic muscle cells, without nuclei and cytoplasmic cross-striations and granulocyte and macrophage infiltration between them was seen in the acute myocardial infarction. Proliferation of connective tissue between myocardial cells indicates formation of a post-infarction scar (Fig. 2).
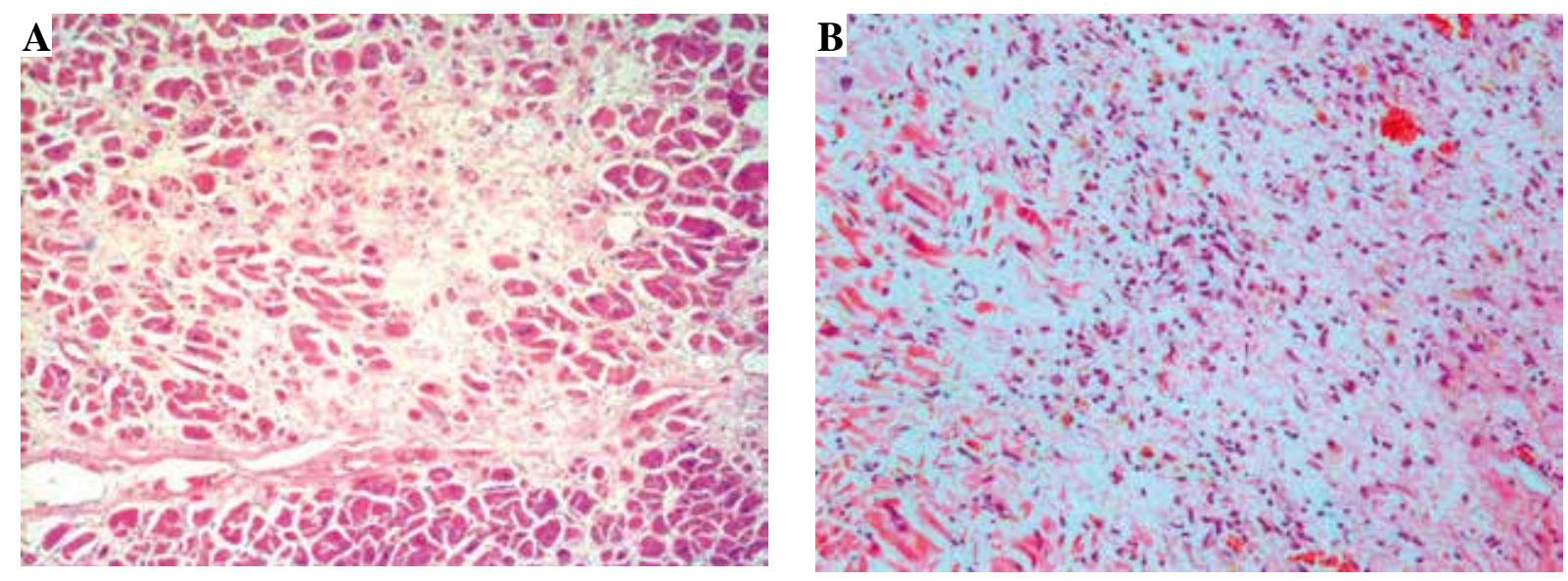

Fig. 2. Morphological assessment of the examined myocardial tissue was done on the basis of the routine hematoxylin and eosin staining. Scale $100 \mu \mathrm{m}$ 
Immunohistochemical examination provided positive results in all cases: staining of numerous muscle cells inside and outside the necrotic zone as well as in blood vessels.

Positive reaction for the complement component $\mathrm{C} 4 \mathrm{~d}$ was present on the surface of the whole myocardial section, and was most intensive in the luminal segment of the coronary artery. Complement component $\mathrm{C} 9$ was also located on the surface of the whole myocardial section, while the highest immunoreactivity was found in the luminal segment of the coronary artery. Numerous positively staining fibers were found in the necrotic zone (Fig. 3).

Staining for CD55 demonstrated accumulation of immunoreactivity for this inhibitor on the surface of the endothelium, and for inhibitor CD59 - in the wall of the coronary artery. Positive reaction for membrane inhibitors CD55 and CD59 was found in the necrotic zone. Numerous positively staining cells were found outside the necrotic zone both for CD55 and CD59 (Fig. 4).

Staining for factor $\mathrm{H}$ demonstrated the highest immunoreactivity of this inhibitor in the luminal segment of the coronary artery. Numerous positively staining cells were
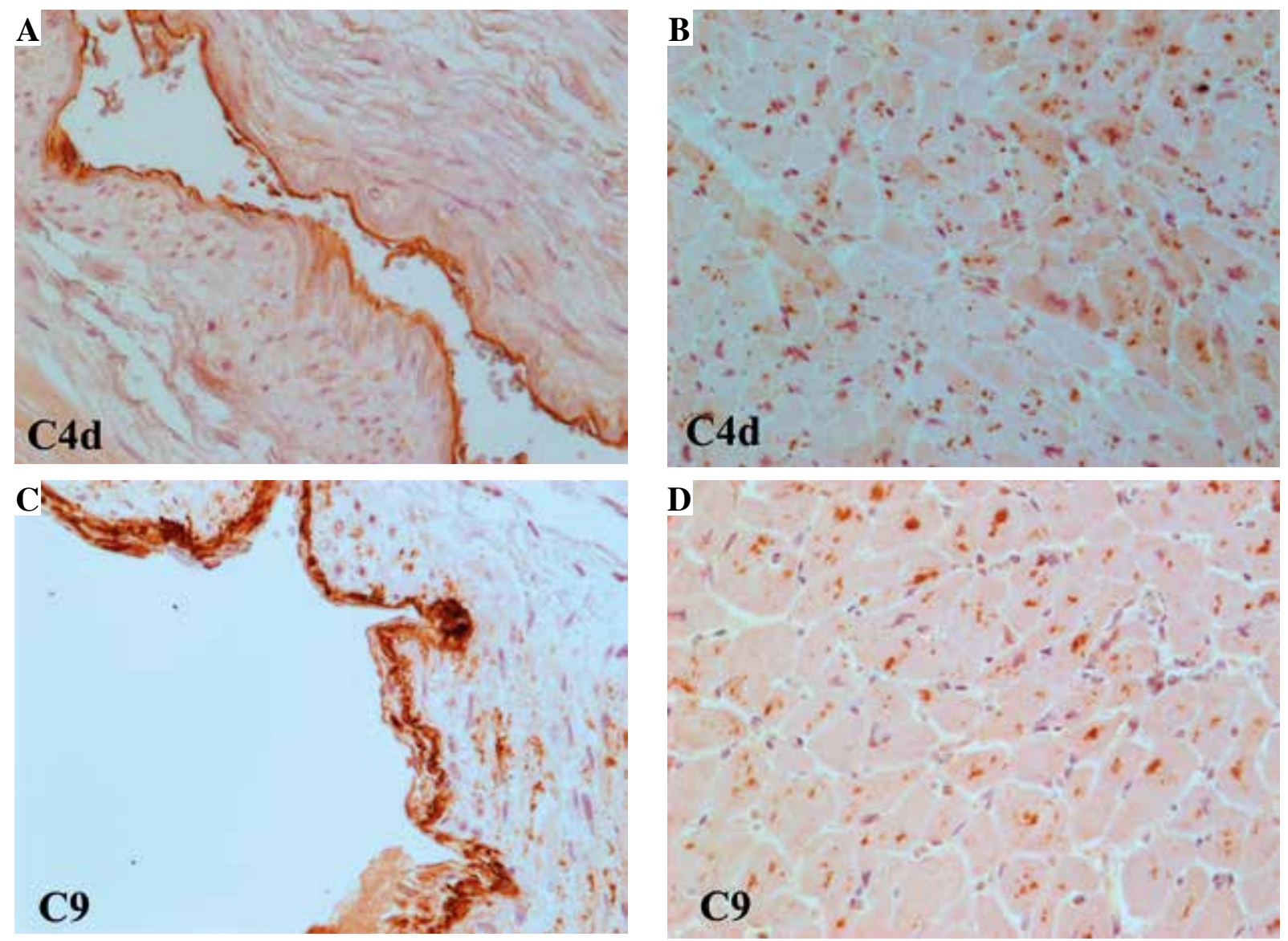

Fig. 3. Immunoreactivity of the complement proteins (C4d and C9) in the examined tissue material. High staining intensity could be seen on the surface of coronary endothelium and moderate staining intensity on single myocardial cells. Scale $50 \mu \mathrm{m}$ found on the surface of the whole section, and occasional positively staining cells were found in the necrotic zone (Fig. 5).

\section{Discussion}

Myocardial cells from the infarcted heart start expressing foreign antigens for the immune system of the body. This results in strong activation of the complement system and accumulation of extensive deposits of components of the final pathway C5b-9, MAC [14]. Studies presented in this paper demonstrated colocalization of the complement components and inhibitors in the myocardial tissue. Immunohistochemical reaction for the complement components and inhibitors examined under the light microscope, demonstrated widespread abundance of these proteins in the tissues. Positive immunohistochemical reaction was found in the myocardial cells, intercellular matrix as well as in the vessel lumens [15].

Available literature lacks detailed studies examining the role of the complement system and its inhibitors in 

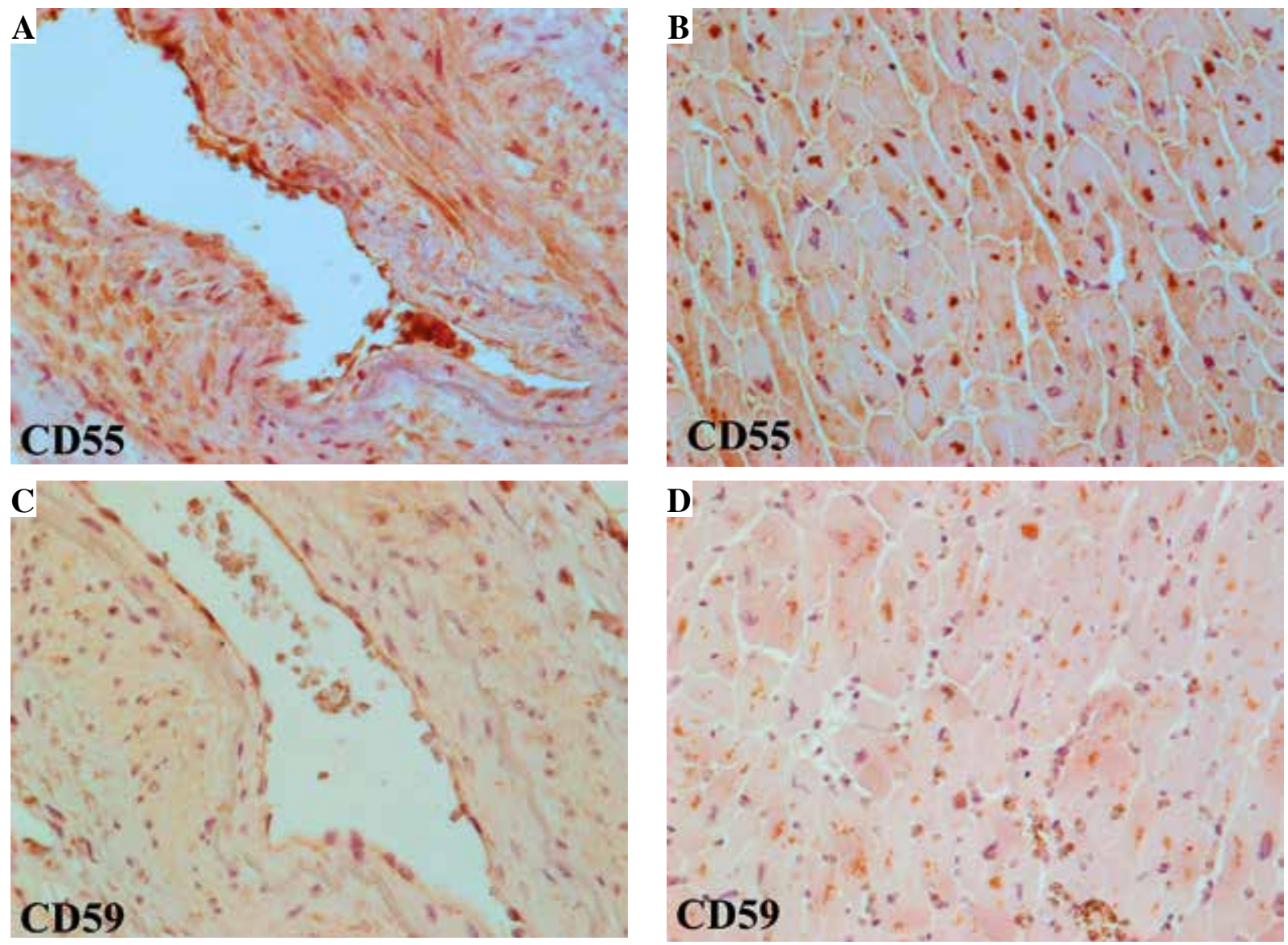

Fig. 4. Immunoreactivity of membrane complement inhibitors (CD55, CD59) in the tested tissue material. Intensive immunohistochemistry reaction could be seen on the surface of coronary endothelium and weak immunoreactions in sporadic myocardial cells. Scale $50 \mu \mathrm{m}$
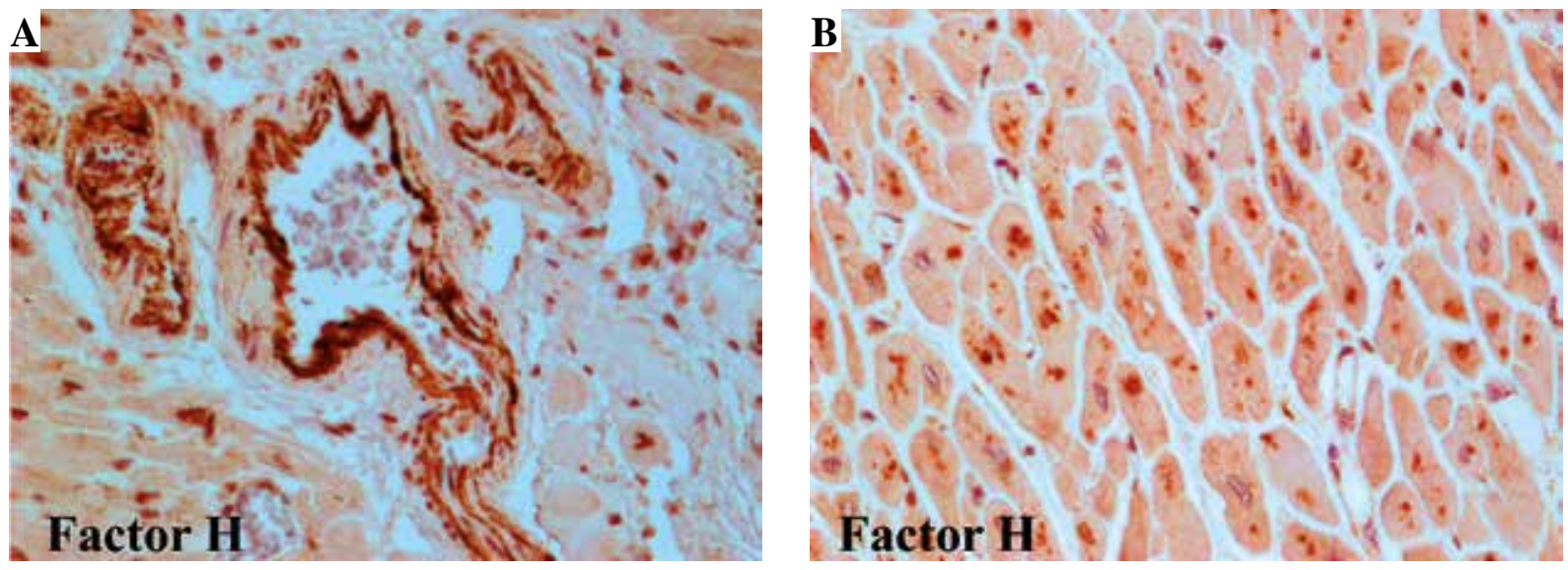

Fig. 5. Immunoreactivity of membrane complement inhibitors (factor $\mathrm{H}$ ) in the tested tissue material. Intensive immunohistochemistry reaction could be seen on the surface of coronary endothelium and weak immunoreactions in sporadic myocardial cells. Scale $50 \mu \mathrm{m}$ 
the development and pathogenesis of myocardial infarction. The role of complement in the myocardial ischemia is mentioned only in few reports [16-24].

Studies conducted in experimental models of myocardial infarction demonstrated a potential pathophysiological role of activation of the complement system as a result of tissue ischemia. A classical component pathway was proven to be the principal complement activation pathway during injuries caused by myocardial ischemia. Serum proteins (C1-inhibitor) were used both to inhibit the effector phase as well as in later stages to reduce the infarct size [14]. Carrier et al. investigated the effect of the C5 blocking antibody on the mortality rate and occurrence of myocardial infarction in patients undergoing a coronary artery bypass grafting procedure. Beneficial effects of this antibody were demonstrated, although the authors recommended confirmation of the magnitude of mortality reduction in further studies $[25,26]$. Granger et al. investigated effects of pexelizumab and C5 antibody treatment on reduction of the mortality rate in patients with acute myocardial infarction undergoing percutaneous coronary intervention. They demonstrated that the combination treatment had a significant effect on protection of the myocardium during reperfusion and resulted in reduction of mortality. However, the authors in this case also recommended further studies [27]. On the other hand, Mahaffey et al. investigated the effect of pexelizumab and C5 antibody treatment as an adjunctive therapy with fibrinolysis in the acute myocardial infarction. Results of this study demonstrated that the proposed adjunctive treatment had no significant effect on the myocardial infarct size. Furthermore, this new therapy was well tolerated and was not associated with an increased risk of infection or myocardial infarction [28]. These were one of the first attempts of practical use of knowledge about the possibility of inhibition of detrimental complement activation.

After analyzing these results, we decided to study the selected components as well as inhibitors of the complement system in the myocardium subjected to ischemic necrosis, using morphological techniques and immunohistochemical reactions. Basing on conducted immunohistochemical staining and analysis of obtained results of this reaction we demonstrated the existence of complement proteins (C4d, C9) and colocalization of membrane (CD55, CD59) and soluble (factor H) complement inhibitors. Presence of complement inhibitors on the myocardial cells from the heart subjected to ischemic necrosis raises the question: why large amounts of MAC become deposited and why the infarction-related injury becomes exacerbated? Abnormal functioning of the complement system may have variable origin. Mutations of genes responsible for expression of important regulators of the complement system (CD59 in this case) or specific components of the complement cascade may be one of such causes [29].

\section{Summary}

Immunohistochemical identification of the complement proteins and inhibitors demonstrated their common presence on the surface of the myocardium subjected to ischemic necrosis. The abnormal function of the complement system may be caused by various factors, including mutations of genes responsible for expression of important regulators of the complement system or respective components of the complement cascade. Establishment of a haplotype that predisposes to the development of myocardial infarction and related abnormalities of the complement system may be a significant step towards understanding of etiology and development of new therapeutic strategies for this disorder. Therefore, studies of the complement system, such as discussed in this paper, should be continued and extended using modern research techniques to potentially contribute to effectively fight the diseases against which modern medicine remains largely helpless.

The presented work was supported by the Medical University of Warsaw funding no. 1M11/N/12:Material.

The authors declare no conflict of interest.

\section{References}

1. Derzhko R, Witkowska M (2010): Glucose metabolism disturbances and the risk of cardiovascular diseases (in Polish). Adr Clin Exp Med 5: 911-916.

2. De Backer G, Ambrosioni E, Borch-Johnsen K, et al. (2003): Third Joint Task Force of European and other Societies on Cardiovascular Diseases Prevention in Clinical Practice. European guidelines on cardiovascular diseases prevention in clinical practice. Eur Heart J 24: 1601-1610.

3. Podolec P, Kopeć G, Pająk A (2006): Konsensus Rady Redakcyjnej Polskiego Forum Profilaktyki Chorób Układu Krążenia dotyczący oceny ryzyka sercowo-naczyniowego. Forum Profilaktyki 2: 2.

4. Ilczuk T, Wasiutynski A (2013): Role of complement factors and their inhibitors in the myocardial infarction. Centr Eur J Immunol 38: 251-253.

5. Alpert JS, Thygesen K, Antman E, Bassand JP (2000): Myocardial infarction redefined - a consensus document of the Joint European Society of Cardiology/American College of Cardiology/Committee for the redefinition of myocardial infarction. Eur Heart J 21: 1502-1513; J Am Coll Cardiol 36: 959-969.

6. Thygesen K, Alpert JS, White HD; Joint ESC/ACCF/AHA/ WHF Task Force for the Redefinition of Myocardial Infarction (2007): Universal definition of myocardial infarction. Eur Heart J 28: 2525-2538; Circulation 116: 2634-2653; J Am Coll Cardiol 50: 2173-2195.

7. Kumar V, Cotran RS, Robbins SL (2013): Basic Pathology. Włodzimierz T. Olszewski (red. wyd. pol.). Wydawnictwo Medyczne Urban \& Partner, Wrocław: 374-453.

8. Kruś S, Skrzypek-Fakhoury E (2011): Patomorfologia kliniczna. Wydanie III. Wydawnictwo Lekarskie PZWL, Warszawa: 74-77, 258-297. 
9. Sochacka M, Błach-Olszewska Z (2006): Mechanisms of innate immunity (in Polish). Post Hig Med Dośw 59: 250-258.

10. Morgan BP (2000): Regulation of the complement membrane attack pathway. Crit Rev Immunol 19: 173-198.

11. Rodríguez de Córdoba S, Esparza-Gordillo J, Goicoechea de Jorge E, et al. (2009): The human complement factor H: functional roles, genetic variations and disease associations. Mol Immunol 41: 355-367.

12. Gołąb J, Jakóbisiak M, Lasek W, et al. (2011): Immunologia. Wydawnictwo Naukowe PWN, Warszawa: 66-77.

13. Wojnicz D, Bar J, Jankowski S (2002): The role of membrane glycoproteins CD46, CD55 and CD59 in protection of tumor cells against complement lysis (in Polish). Post Hig Dośw 56: 603-616.

14. Walport MJ (2001): Complement. Second of two parts. N Engl J Med 344: 1140-1144.

15. Frank HG, Malekzadeh F, Kertschanska S, et al. (1994): Immunohistochemistry of two different types of placental fibrinoid. Acta Anat (Basel) 150: 55-68.

16. Lucchesi BR, Kilgore KS (1997): Complement inhibitors in myocardial ischemia/reperfusion injury. Immunopharmacology 38: 27-42.

17. Tada T, Okada H, Okada N, et al. (1997): Membrane attack complex of complement and 20kDa homologous restriction factor (CD59) in myocardial infarction. Virchows Arch 430: 327-332.

18. Lazar HL, Bao Y, Gaudiani J, et al. (1999): Total complement inhibition: an effective strategy to limit ischemic injury during coronary revascularization on cardiopulmonary bypass. Circulation 100: 1438-1442.

19. Kręcki R, Krzemińska-Pukała M, Kasprzak J (2009): Reperfusion injury inhibitors myocardial infarction - another milestone in the treatment of acute coronary syndromes? (in Polish). Choroby Serca i Naczyń 2: 81-86.

20. Diamond LE, McCurry KR, Oldham ER, et al. (1995): Human CD59 expressed in transgenic mouse hearts inhibits the activation of complement. Transpl Immunol 3: 305-312.

21. Väkevä A, Laurila P, Meri S (1992): Loss of expression of protectin (CD59) is associated with complement membrane attack complex deposition in myocardial infarction. Lab Invest 67: 608-616.

22. Weisman HF, Bartow T, Leppo MK, et al. (1990): Soluble human complement receptor type 1: in vivo inhibitor of complement suppressing post-ischemic myocardial inflammation and necrosis. Science 249: 146-151.

23. Williams JP, Pechet TT, Weiser MR, et al. (1999): Intestinal reperfusion injury is mediated by IgM and complement. J Appl Physiol 86: 938-942.

24. Wust SK, Blumenthal MN, Corazalla EO, et al. (2006): Complement in asthma: sensitivity to activation and generation of $\mathrm{C} 3 \mathrm{a}$ and $\mathrm{C} 5 \mathrm{a}$ via the different complement pathways. Transl Res 148: 157-163.

25. Carrier M, Ménasché P, Levy JH, et al. (2006) Inhibition of complement activation by pexelizumab reduces death in patients undergoing combined aortic valve replacement and coronary artery bypass surgery. J Thorac Cardiovasc Surg 131: 352-356

26. Klaska I, Nowak JZ (2007): The role of complement in physiology and pathology. Post Hig Med Dośw (Online) 61: 167-177.

27. Granger CB, Mahaffey KW, Weaver WD, et al. (2003): Pexelizumab, an anti-C5 complement antibody, as adjunctive therapy to primary percutaneous coronary intervention in acute myocardial infarction. Circulation 108: 1184-1190.
28. Mahaffey KW, Granger CB, Nicolau JC, et al. (2003): Effect of pexelizumab, an anti-C5 complement antibody, as adjunctive therapy to fibrinolysis in acute myocardial infarction. Circulation 108: 1176-1183.

29. Wojtczak A, Skrętkowicz J (2007): Genetic determinants of cardiovascular diseases (in Polish). Pol Merk Lek 133: 5-8. 